effect on the locomotor muscles. The respiratory muscles might be expected to hypertrophy under the increased demand imposed by disease, but surprisingly what are usually found are increased fatigability and atrophy. In particular, fatigue of the inspiratory muscles may be important in limiting exercise tolerance. ${ }^{27}$

How, then, may the respiratory muscles be trained? The answer is breathing against resistance, which increases tidal volume, decreases the respiratory rate, and increases effort tolerance. Respiratory muscle endurance training can also increase exercise capacity in chronic obstructive airways disease, sometimes by as much as half, but generally less. ${ }^{822}$ Nevertheless, some patients deteriorate during exercise because of severe fatigue of the diaphragm. The selection of appropriate patients on clinical grounds is difficult: it requires the services of elaborate muscle function laboratories. For that reason the recent report of Sonne and Davis is of interest. ${ }^{8}$ Six patients with moderate to severe airways obstruction entered a six week training programme using a resistance "whistle" with variable orifice, one way valve, and mouthpiece. Training was aimed at the inspiratory muscles and was performed for 30 minutes daily. The maximal work rate increased by $37 \%$ and $\mathrm{Vo}_{2} \max$ by $15 \%$. Clearly some patients derive considerable benefit from simple training programmes of this type. Further studies of respiratory muscle function in patients with chronic obstructive airways disease should be performed to maximise benefit from such training programmes.

T W Evans Research fellow

P Howard

Academic Division of Medicine, Reader in medicine

University of Sheffield,

Sheffield S10 2JF

\footnotetext{
Ogilvie C. Dyspnoea. Br.Med I 1983;287:160-1.
Woodcock AA, Gross ER, Gellert A, Shah S, Johnson M, Geddes EM. Effects of dihydrocodenine, alcohol and caffeine on breathlessness and exercise tolerance in patients with chronic obstructive lung disease and normal blood gases. N Engl f Med 1981;305:1611-6.

Woodcock AA, Gross ER, Geddes EM. Oxygen relieves breathlessness in "pink puffers." Lance 1981;i:907-9.

Waterhouse JC, Howard P. Breathlessness and portable oxygen in chronic obstructive airways disease. Thorax 1983;38:302-6.

Evans TW', Howard P. Short burst oxygen therapy for breathlessness in chronic obstructive airways disease. Clin $S_{c i} 1984 ; 66: 56$

Saltin B, Bllomqvist G, Mitchell JH, Johnson RJ Jr, Wildenthal K, Chapman CB. Response to exercise after bed rest and after training. A longitudinal study of adaptive changes in oxygen

Barachal AL, Petty TL. Is chronic obstructive lung disease improved by physical exercise? JAMA 1975;234:854-

inspiat Davis JA. Increased exercise performance in patients with severe COPD following inspiratory resistive training. Chest $1982 ; 81: 435-8$.

ery LE, Karlman $W^{\prime}$, French $W$, Oven A, Davis JA. Contrasting cardiovascular and chronic obstructive pulmonary disease. Chest 1983;3:446-53. chronic bronchitis. Br.Med $\mathcal{O} 1976 ; 1: 822-3$.

Mertens DJ, Roy J, Shephard RJ, Kavanagh T. Long term exercise therapy for chronic obstructiv lung disease. Respiration 1978;35:96-107.

Morgan AD, Peck DS, Bucannon DR, McHardy GJR. Effects of attitudes and beliefs on exercise tolerance in chronic bronchitis. Br Med F 1983;286:171-3.

Pardy RL, Rivington RN, Despas JP, Macklean PI. The effects of inspiratory muscle training on exercise performance in chronic airflow limitation. Am Rev Respir Dis 1981;123:426-33.

Pierce AK, Taylor HF, Archer RR, Miller WF. Responses to exercise training in patients with emphysema. Arch Intern Med 1964;113:26-36

Paez PN, Phillipson EA, Massangkay M, Sproule BJ. The physiological basis of training in patients with emphysema. Am Rev Respir Dis 1967;96:944-53.

egre S, Sergysels R, Messin R, et al. Hemodynamic responses to physical training in patients with

chronic lung disease. Am Rev Respir Dis 1974;110:394-402.

hemodynamics and pulmonary function at rest and during exercise in patien physical training on 1974;66:647-51.

${ }^{18}$ Petty TL, Nett LM, Finigan MM. A comprehensive care program for chronic airways obstruction Ann Intern Med 1969;70:1109-20.

Guthrie AG, Petty TL. Improved exercise tolerance in patients with chronic airway obstruction.

Jounral of the American Physiotherapy Association 1970;50:1333.
${ }^{20}$ McGavin CR, Gupta SP, Lloyd EL, McHardy GIR. Physical rehabilitation for the chronic bronchitic: results of a controlled trial of exercises in the home. Thorax 1977;32:307-11

Longo AM, Moser KM, Luchsinger PC. The role of oxygen therapy in the rehabilitation of patients with chronic obstruction pulmonary disease. Am Rev Respir Dis 1971;103:690-7

Belman MJ, Kendregan BA. Physical training fails to improve ventilatory muscle endurance in patients with chronic obstructive pulmonary disease. Chest 1982;81:440-

hypoxic cor pulmonale complicating chronic bronchitis and emphysema. Lance t $1981 ; .681-5$ hypoxic cor pulmonale complicating chronic bronchitis and emphysema. Lancet $1981 ; i: 681-5$.
Pierce AK, Paez PM, Miller WF. Exercise training with the aid of a portable oxygen supply to Pierce AK, Paez PM, Miller WF. Exercise training with the ais
patients with emphysema. Am Rev Respir Dis 1971;103:690-7.

Levine BE, Bigilow DV, Hamstra RD. The role of long term continuous oxygen therapy in patients with chronic airways obstruction with hypoxemia. Am Rev Respir Dis 1971;103:690-7.

Woolf CR, Suero JT. Alterations in lung mechanics and gas exchange following training in chronic obstructive lung disease. Chest 1969;55:37-44.

${ }^{27}$ Macklem PT. Respiratory muscles: the vital pump. Chest 1980;78:753-8.
}

\section{True left ventricular aneurysm}

The pathologist defines a true left ventricular aneurysm as "a protrusion of a localised portion of the external aspect of the left ventricle beyond the remainder of the cardiac surface with simultaneous protrusion of the cavity." Angiographically, a left ventricular aneurysm is described as a motion disturbance of the myocardium where a part of the left ventricular wall shows localised akinesia or dyskinesia during the systolic phase of a cineangiogram..$^{23}$

The most common cause of left ventricular aneurysm is myocardial infarction but it may be due to a congenital defect, trauma, bacterial endocarditis, myocardial abscess, syphilis, or Chagas's disease, ${ }^{4}$ or be of the African idiopathic mitral subannular type.

The incidence of left ventricular aneurysm in survivors of acute myocardial infarction depends on the definition used: figures are quoted from $4 \%$ in necropsy series to $40 \%$ in angiographic series. ${ }^{67}$ Furthermore, the interval from myocardial infarction to clinical presentation with a left ventricular aneurysm may be as long as three years. ${ }^{89}$ Patients who present only weeks after myocardial infarction have an especially poor prognosis. ${ }^{10}$

Symptoms that should arouse suspicion of a left ventricular aneurysm include persistent left ventricular failure and angina pectoris and, less commonly, recurrent ventricular tachyarrhythmias and thromboembolism. There are no diagnostic physical signs, though an expansile or double apex beat may be highly suggestive. ${ }^{11}$ The heart is usually enlarged on the chest $x$ ray film, but an aneurysm bulge is unusual." Calcification may be seen in the wall of the aneurysm. Most patients have a persistent rise in the ST segment on the electrocardiogram, ${ }^{811}$ and a dominant $R$ wave in lead aVF may be a helpful pointer. ${ }^{6}$

Confirmation of a clinical suspicion of left ventricular aneurysm relied entirely on left ventricular cineangiography until the advent of non-invasive techniques. $M$ mode echocardiography is of limited value, but it is available in many peripheral general hospitals and diagnostic criteria for left ventricular aneurysm have recently been defined in a series of patients with severe cardiac failure and previous transmural myocardial infarction..$^{12}$ If the left ventricular cavity at the level of the mitral ring is greater than $6 \mathrm{~cm}$ at end systole or if fibre shortening (end diastolic diameter-end systolic diameter) divided by end diastolic diameter is less than $15 \%$, then a left ventricular aneurysm is unlikely. Over $90 \%$ of patients with left ventricular aneurysm have fibre shortening greater than $20 \%$ and opening of the mitral valve delayed by $80 \mathrm{~ms}$ or more. Further evaluation of these measures is warranted.

In skilled hands two dimensional echocardiography can allow differentiation of left ventricular aneurysm from diffuse left ventricular dilatation ${ }^{71}$ and also detect mural thrombi. " False left ventricular aneurysm (rupture of the left ventricular wall, the haematoma being contained by the adherent pericardium and extracardiac structures) has a poor prognosis for the defect often ruptures completely. ${ }^{13}$ The important differentiation between true and false aneurysms is aided by two dimensional echocardiography: true left ventricular aneurysms have a wide mouth while false aneurysms often extend behind the intact left ventricular wall and have a narrow neck. ${ }^{14}$

Non-invasive radionuclide techniques provide another range of methods for accurate screening for left ventricular 
aneurysm, assessment of the contractile segment, and differentiation from diffuse left ventricular hypokinesis. ${ }^{13} 15$ A giant aneurysm of the anterior wall may be incorrectly diagnosed, however - an error made less likely by additional scintigraphic views and two dimensional echocardiography. ${ }^{16}$

Untreated, patients with a left ventricular aneurysm have a $90 \%$ chance of dying within five years of their myocardial infarction. ${ }^{17}{ }^{18}$ Such global figures must be qualified by the statement that prognosis depends on several factors and, in particular, the overall left ventricular performance. Death usually results from recurrent myocardial infarction with or without left ventricular failure.

Patients should be referred for consideration of surgery when the maximum appropriate medical treatment has failed. ${ }^{19}$ All patients, especially those with severe left ventricular failure, must be fully assessed with attention paid to the function of the non-aneurysmal contractile segment of the left ventricle, the severity of occlusive coronary artery disease, and the presence and severity of mitral regurgitation. ${ }^{20}$ Both the variable operative mortality (4-50\%) and the clinical prognosis depend on these factors. ${ }^{21} 22$ Radionuclide angiography and two dimensional echocardiography are playing an increasing part in the preoperative (and postoperative) assessment of left ventricular function. ${ }^{23}$

Many patients with severe left ventricular failure are much relieved after combined aneurysmectomy and coronary artery bypass surgery. ${ }^{19} 24$ Some, however, have disappointing results despite apparently good contraction of the nonaneurysmal segment on preoperative assessment. Indeed, a paradoxical inverse relation has been reported between the extent of any improvement in postoperative left ventricular function and the function of the remaining viable segments. ${ }^{25}$ In patients who are not in failure aneurysmectomy with coronary artery bypass for refractory angina carries a low operative mortality $(4 \%)$ and a five year survival of about $75 \% .{ }^{26}$

Mural thrombi are present in about half of all left ventricular aneurysms. The incidence of clinically recognised embolism is low at $5 \%$, but necropsy studies show a higher incidence, of about $30 \% .{ }^{27}$ The presence of mural thrombus correlates inversely with the duration of treatment with anticoagulants, and the effect of anticoagulants should be assessed before considering aneurysmectomy for peripheral embolism.

Aneurysmectomy for ventricular tachyarrhythmias may help many patients, but the results are unpredictable, and the operative mortality approaches $60 \%$ within a month of acute myocardial infarction. ${ }^{192}$ The site of origin of such arrhythmias may be distant from the aneurysm. Electrophysiological mapping may help in its location: an encircling ventriculotomy or endomyocardial resection may then be beneficial. ${ }^{29}$ Clearly a thorough trial of medical treatment should be given before surgery.

What has emerged from recent research is that patients with left ventricular aneurysms after myocardial infarction form a heterogeneous group. The main determinant of the clinical course and outcome of surgery is the state of the coronary arteries, which in turn determines the function of the non-aneurysmal segment of the left ventricle and the size of the left ventricular aneurysm. More studies of clearly defined subgroups of these patients are needed.

David A TibButt

Consultant Physician

Worcester Royal Infirmary,

Worcester WR1 3AS
Edwards JE. An atlas of acquired diseases of the heart and great vessels. Vol II. Philadelphia: WB Saunders, $1961: 615-29$

Med 1967;42:512-3

Lee DCS, Johnson RA, Boucher CA, Wexler LF, McEnany TM. Angiographic predictors of survival following left ventricular aneurysmectomy. Circulation 1977;56(suppl 2):12-8.

Oliveira JSM, de Oliveira JAM, Frederique U, Filho ECL. Apical aneurysms of Chagas's heart disease. Br Hear $\mathrm{f}$ 1981;46:432-7.

itchett DH, Kanji M. Mitral subannular left ventricular aneurysm. Br Heart J 1983;50:594-6. Goldberg MJ. Left ventricular aneurysm. Br J Hosp Med 1982;27:143-54.

sser CA, Kan G, David GK, Lie KI, Durrer D. Echocardiographic-cineangiographic correlation in detecting left ventricular aneurysm: a prospective study of 422 patients. Am $\mathcal{J}$ Cardio

${ }^{8}$ Graber JD, Oakley CM, Pickering BN, Goodwin JF, Raphael MJ, Steiner RE. Ventricular neurysm: an appraisal of diagnosis and surgical treatment Br $H$ eart $\mathcal{f} 1972 \cdot 34: 830-8$.

1972;29:1-6.

10 Walker WE, Stoney WS, Alford WC, Burrus GR, Glassford DM, Thomas CS. Results of surgical

management of acute left ventricular aneurysms. Circulation 1980;62(suppl 1):75-8.
11 Baur HR, Daniel JA, Nelson RR. Detection of left ventricular aneurysms on two dimensional echocardiography. Am J Cardiol 1982;50:191-6.

${ }^{12} \mathrm{Hall}$ RJC. M-mode echocardiography in the detection of surgically resectable left ventricular aneurysm. Eur Hean f 1983;4:230-7.

Winzelberg GG, Strauss HW, Bingham JB, McKusick KA. Scintigraphic evaluation of left ventricular aneurysm. Am $\mathcal{f}$ Cardiol 1980;46:1138-43.

4 Gatewood RP, Nanda NC. Differentiation of left ventricular pseudoaneurysm from true aneurysm with two dimensional echocardiography. Am $\mathcal{F}$ Cardiol 1980;46:869-78.

Erlebacher JA, Becker LC, Weiss JL, Leitl GP, Achuff SC, Fortuin NJ. Clinical recognition of giant left ventricular aneurysm. Am $\mathcal{F}$ Med 1981;71:799-805.

Dymond DS, Stephens J, Stone D, et al. Assessment of function of contractile segments in patients withleft ventricular

Mourdjinis A, Olsen E, Raphael MJ, Mounsey JPD. Clinical diagnosis and prognosis of ventricular aneurysms. Br Hear $\mathcal{F}$ 1968;30:497-513.

18 Nagle RE, Williams DO. Natural history of ventricular aneurysm without surgical treatment. $B r$ Hear $\mathcal{f}$ 1974;36:1037.

${ }^{19}$ Cohen M, Packer M, Gorlin R. Indications for left ventricular aneurysmectomy. Circulation 1983;67:717-22.

${ }^{20}$ Gold FL, Sharmer B, Hodges M, Helseth HK. Combined left ventricular aneurysmectomy, mitral valve replacement and aortocoronary bypass grafting: results of surgery. Circulation 1980; 62(suppl 1):147-52.

${ }^{21}$ Najafi $\mathrm{H}$, Meng $\mathrm{R}$, Javid $\mathrm{H}$, et al. Postmyocardial infarction left ventricular aneurysm. Cardiovasc

Brawley RJ, Magovern GJ, Gott VC, Donahoo JS, Gardner TJ, Watkins L. Left ventricular aneurys $85.712-7$

3 Froehlich RT, Falsetti HL, Doty DB, Marcus ML. Prospective study of surgery for left ventricular aneurysm. Am $\mathcal{F}$ Cardiol 1980;45:923-31.

${ }^{24}$ Borer JS, Jacobstein JG, Bacharach SL, Green MV. Detection of left ventricular aneurysm and evaluation of effects of surgical repair; the role of radionuclide cineangiography. Am $\mathcal{f}$ Cardiol 1980;45:1103-6.

${ }^{25}$ Stephens JD, Dymond DS, Stone DL, Rees GM, Spurrell RAJ. Left ventricular aneurysm and congestive heart fallure; value of exercise stress and isosorbide dinitrate in predicting

demodynamic results of aneurysmectomy. Am $\mathcal{J}$ Cardiol 1980;45:932-9.
${ }^{26}$ Rittenhouse EA, Sauvage LR, Mansfield PB, et al. Results of combined left ventricular aneurysmectomy and coronary artery bypass: 1974 to 1980 . Am $\mathcal{f}$ Surg 1982;143:575-8.

Reeder GS, Lengyel M, Tajik AJ, Seward JB, Smith HC, Danielson GK. Mural thrombus in left ventricular aneurysm. Mayo Clin Proc 1981;56:77-81.

da AJ, Stinson EB, Harrison DC. Surgery for life-threatening ventricular tachyarrhythmias. $\mathrm{Am}$

f Cardool 1979;44:1171-7.
Harken AH, Horowitz LN, Josephson ME. Comparison of standard aneurysmectomy and

neurysmectomy with directed endocardial resection for the treatment of recurrent sustained
ventricular tachycardia. F Thorac Cardiovasc Surg 1980;80:527-34.

\section{Deputising services}

Facts have been in short supply during the recent debate on problems associated with deputising services in general practice-but opinion has abounded and has at times been based on wishful thinking. If rational decisions on future policy are to be made the facts need to be distinguished and recognised.

Evening, night, and weekend visits make up only $1 \%$ to $3 \%$ of general practice consultations, ${ }^{1-3}$ but they arouse strong emotions in both doctors and patients. ${ }^{4}$ Over $40 \%$ of night visits are currently carried out by deputising services. ${ }^{5}$ When a call has been received deputising services usually respond by visiting the patient. ${ }^{67}$ General practitioners are much more likely to respond with telephone advice. ${ }^{1-3} \mathrm{~A}$ paper by Sheldon and Harris ( $p$ 474) confirms a previous report that use of deputising services was associated with a substantial increase in night visiting. ${ }^{8}$ No evidence exists to suggest which approach to calls represents good clinical practice.

On the whole, those deputising services which have been studied appear to respond to calls reasonably quickly. ${ }^{69}$ The appropriateness of delays is, however, difficult to judge from published work: patients are more likely to complain that the delay in visiting has been longer, ${ }^{10-12}$ or longer than 